Original Research Paper

\title{
Pemberdayaan Ekonomi Masyarakat Pesisir Melaui Peningkatan Keterampilan Pengolahan Hasil Perikanan di Desa Labuan Lombok, Kecamatan Pringgabaya Kabupaten Lombok Timur
}

\author{
M. Yusuf ${ }^{*}$, Halimatus Sa'diyah ${ }^{1}$, Syarif Husni ${ }^{1}$, Muhammad Nursan ${ }^{1}$, Aeko Fria Utama ${ }^{1}$, Ni \\ Made Nike Zeamita Widiyanti ${ }^{1}$ \\ ${ }^{1}$ Program Studi Agribisnis, Universitas Mataram, Indonesia
}

https://doi.org/10.29303/jpmpi.v3i2.1435

Sitasi: Yusuf, M., Sa'diyah, H., Husni, S., Nursan, M., Utama, A. F \& Wiidiyanti, N. M. N. Z. (2022). Pemberdayaan Ekonomi Masyarakat Pesisir Melaui Peningkatan Keterampilan Pengolahan Hasil Perikanan di Desa Labuan Lombok, Kecamatan Pringgabaya Kabupaten Lombok Timur. Jurnal Pengabdian Magister Pendidikan IPA, 5(1)

Article history

Received: 10 Januari 2022

Revised: 22 Februari 2022

Accepted: 25 Februari 2022

*Corresponding Author: M. Yusuf, Program Studi Agribisnis, Universitas Mataram, Indonesia. Email: yusuf@unram.ac.id

\section{Pendahuluan}

Lombok Timur merupakan salah satu kabupaten di Provinsi Nusa Tenggara Barat (NTB) yang memiliki potensi penangkapan dan pengelolaan ikan di laut yang cukup besa. Hal ini didukung oleh adanya garis pantai sepanjang yang

\begin{abstract}
The general objective of implementing this community service is to increase the knowledge and skills of coastal communities, especially women fishermen about fish processing techniques, while the specific objectives are: (1) Increasing the knowledge and skills of women fishermen about technical, socio-economic and other aspects of fishery products processing business; (2) Showing the public about good, healthy, and environmentally friendly fish processing techniques and (3) Establishing relationships between universities, especially Mataram University and the community. The implementation of the activities is carried out using an adult education approach (andragogy) which is carried out through counseling and demonstrations to partner groups. The results of the activity show that: (1) This community service activity has been able to improve the knowledge and skills of partner groups, especially those related to: (a) technical, socio-economic and other aspects of fishery product processing (fish processing), (b) good, healthy, and environmentally friendly fishery product processing techniques; and (c) management capability of coastal community groups, especially women fishers processing fishery products in an effort to take advantage of existing potentials; and (2) This community service activity also encourages intensive communication as reciprocity between universities in this case the Faculty of Agriculture, UNRAM and coastal communities, especially women who are members of the fishermen's group processing fishery products (fish farmers in Labuhan Lombok Village, Lombok). Pringgabaya District, East Lombok Regency.
\end{abstract}

Keywords: economic empowerment, fishery product processing technology, women fisherman groups

cukup $\pm 40 \mathrm{~km}$. Namun, dengan realitas sosial yang ada saat ini, tidak kurang 1/3 daerah yang terletak di kawasan pesisir, Timur dan Selatan wilayah Kabupaten Lombok Timur dikategorikan sebagai daerah yang memiliki penduduk miskin yang cukup banyak dibandingkan dengan wilayah lain di daerah ini (M. Yusuf, Syarif Husni, dan Abubakar, 2018). Program pengentasan kemiskinan di 
wilayah ini telah banyak diberikan pemerintah, namun permasalah kemiskinan tetap menjadi isu tiap tahunnya. Masalah kompleks yang dihadapi masyarakat pesisir adalah kemiskinan, keterbatasan pengetahuan untuk pengelolaan sumberdaya dan teknologi, serta peran aktif antara pihak luar dengan masyarakat pesisir sehingga dapat menghidupkan kualitas dan keterampilan masyarakat pesisir tanpa melunturkan karakter budayanya (Naui dan Nikmawatisusanti, 2016)

Guna meningkatkan kesejahteraan dan mengentas kesmiskinan masyarakat di wilayah pesisir khusunya masyarakat nelayan, maka diperlukan strategi pembangunan masyarakat yang partisipatif. Pembangunan partisipatif erat kaitannya dengan pemberdayaan masyarakat, di mana pada pembangunan partisipatif diperlukan upaya dan langkah-langkah untuk mempersiapkan masyarakat guna memperkuat kelembagaan masyarakat agar mereka mampu mewujudkan kemajuan, kemandirian, dan kesejahteraan dalam suasana keadilan yang berkelanjutan untuk meningkatkan harkat dan martabatnya serta mampu melepaskan diri dari perangkap kemiskinan dan keterbelakangan. Upaya tersebut merupakan salah satu wujud nyata dari pemberdayaan masyarakat.

Setiap anggota masyarakat dalam sebuah komunitas sebenarnya memiliki potensi, gagasan serta kemampuan untuk membawa dirinya dan komunitasnya untuk menuju ke arah yang lebih baik, namun potensi itu terkadang tidak bisa berkembang disebabkan faktor-faktor tertentu. Proses penyadaran masyarakat tersebut dilakukan melalui konsep-konsep pengembangan kapasitas. Pengembangan kapasitas masyarakat adalah bentuk dari upaya pengembangan pengetahuan, sikap dan keterampilan masyarakat agar dapat berperan serta aktif menjalankan pembangunan secara mandiri dan berkelanjutan. Kusnadi (2006) menyatakan bahwa salah satu unsur potensi sosial untuk meningkatkan pendapatan masyarakat pesisir adalah peran serta semua anggota termasuk di dalamnya kaum wanita, khususnya istri nelayan.

Subagia, et. al. (2018) menyatakan bahwa dalam sektor perikanan hanya pria yang melakukan penangkapan ikan di laut, sehingga wanita nelayan dan anggota keluarga linnya relatif mempunyai waktu luang yang bisa dimanfaatkan untuk kegiatan yang lebih bersifat ekonomi produktif. Dengan demikian, dalam menghadapi kerentanan ekonomi dan kemiskinan masyarakat nelayan, pihak yang paling terbebani dan bertanggung jawab untuk mengatasi dan menjaga kelangsungan hidup rumah tangga dalah kaum wanita khusunya istri nelayan.

Selama ini masyarakat pesisir, khusunya wanita nelayan di Kabupaten Lombok Timur tidak memiliki banyak aktivitas, selain mengurus rumahtangga, sehingga mereka memiliki waktu luang yang cukup besar guna meningkatkan ketrampilan dan perbaikan perekonomian keluarga. Waktu luang tersebut bisa digunakan untuk kegiatan pengolahan hasil perikanan terutama untuk diversifikasi pangan lokal. Namun demikian, saat ini kelompok wanita nelayah tersebut belum berkembang sesuai yang diharapkan. Peran publik wanita dalam kehidupan masyarakat pesisir saat ini sudah banyak dijumpai dalam kehidupan masyarakat di Kabupaten Lombok Timur, Khususnya di Desa Labuhan Lombok Kecamatan Pringgabaya.

Desa Labuhan Lombok merupakan salah satu desa pesisir di Kecamatan Pringgabaya Lombok Timur yang memiliki potensi sumber daya laut dan perikanan yang cukup besar. Desa ini mempunyai luas wilayah $\pm 9,70 \mathrm{~km}^{2}$ dengan jumlah penduduk sebanyak 12.509 jiwa yang terdiri atas 6.251 laki-laki dan 6.258 perempuan dengan rumahtangga sebanyak 3.258 KK. Sebanyak $68 \%$ penduduk di wilayah ini bekerja di sektor perikanan yaitu sebagai nelayan. Sebagian besar masyarakt tidak memiliki pendidikan cukup memadai sehingga tidak banyak ragam pekerjaan yang dapat dilakukan masyarakat. Kaum laki-laki di desa ini pada umumnya bekerja sebagai nelayan, baik kepala keluarga ataupun anak laki-laki yang putus sekolah dan telah merasa mampu untuk melaut. Ibu rumah tangga di desa ini juga ada yang bekerja sebagai pedangan ikan, pedagan bakulan, pemindang ikan, pengasap ikan, penjahit, wiraswata, dan beberapa profesi lainnya. Pendapatan dari ibu rumah tangga ini cukup signifikan memberikan pendapatan tambahan bagi keluarga nelayan.

Keterlibatan anggota rumahtanga, khusunya kaum wanita di masyarakat pesisir cukup beragam. Hasil penelitian yang dilakukan oleh Kusnadi (2006) menelaah keterlibatan isteri nelayan dalam mencari nafkah untuk memenuhi kebutuhan rumah tangga. Mereka menjual ikan hasil tangkapan suaminya atau membelinya dari nelayan lain dan menjualnya di pasar lokal atau di 
pasar luar desanya. Kajian-kajian tentang keterlibatan wanita nelayan khususnya ibu rumah tangga di wilayah ini belum banyak dilakukan secara mendalam. Terdapat 56 unit usaha pengolahan hasil perikanan di Desa Labuhan Lombok dengan melibatkan 230 tenaga kerja. Usaha pengolahan hasil perikanan tersebut masih dilakukan secara tradisional, yaitu dengan cara mengawetan dengan sistem pegaraman kemudian dijemur, penggunaan box es pendingin, pengasapan dan pemindangan dan pemindangan ikan. Khususnya untuk kegiatan pemindangan ikan dilakukan pengukusan atau perebusan dalam lingkungan yang mengandung garam dan tahap selanjutnya setelah produk jadi adalah pengemasan. Umumnya pengemasan yang dipakai adalah kerajang bambu ukuran dengan ukuran yang bervariasi.

Beberapa permasalahan yang dihadapi masyarakat pesisir, khususnya wanita nelayan di Desa Labuihan Lombok dalam usaha pengolahan hasil perikanan di wilayah ini antara lain: (1) masih rendahnya pengetahuan dan ketrampilan masyarakat nelayan khusunya wanita tentang teknik pengolahan hasil perikanan yang baik, sehat, dan ramah lingkungan; (2) cara pengolahan dan kemasan terbuka yang menyebabkan daya awet produk hasil perikanan yang masih rendah; (3) teknologi pengolahan hasil perikanan masih bersifat tradisional; (4) hasil tangkapan yang melimpah dan nilai jual rendah; (5), adanya kendala sosial, ekonomi, dan budaya; dan (6) sistem manajemen usaha masih rendah.

Untuk mengatasi permasalah tersebut sekaligus meningkatkan pengetahuan dan ketrampilan wanita nelayan tentang usuaha pemindangan ikan di wilayah ini, maka perlu kegiatan pengabdian kepada masyarakat yang "Pemberdayaan Ekonomi Masyarakat Pesisir Melaui Peningkatan Ketrampilan Pengolahan Hasil Perikanan di Desa Labuan Lombok, Kecamatan Pringgabaya Kabupaten Lombok Timur “

Tujuan umum kegiatan pengabdian pada masyarakat ini adalah meningkatkan pengetahuan dan keterampilaan masyarakat pesisir, khusunya wanita nelayan tentang teknik pengolahan hasil perikanan, sedangkan tujuan khususnya adalah: (1) Meningkatkan pengetahuan dan ketrampilan wanita nelayan tentang aspek teknik, aspek sosial ekonomi dan lainnya dari usaha pengolahan hasil perikanan; (2) Menunjukkan kepada masyakat tentang teknik pengolahan hasil perikanan yang baik, sehat, dan ramah lingkungan; dan (3) Menjalin hubungan antara perguruan tinggi, khususnya Universitas Mataram dengan masyarakat. .

\section{Metode}

Pelaksanaan kegiatan pengabdian pada masyarakat ini dilakukan dengan metode pendekatan pendidikan orang dewasa (andragogi) yang dilakukan melalui penyuluhan dan demontrasi. Kelompok sasaran adalah wanita nelayan yang melakukan usaha pengolahan hasil perikanan di Desa Labuhan Lombok Kecamatan Pringgbaya Kebuapten Lombok Timur. Setiap fenomena yang timbul dianalisis dan ditindak lanjuti secara bersama-sama dengan seluruh unsur masyarakat yang terlibat dalam kegiatan ini. Kegiatan ini melibatkan satu kelompok wanita nelayan pengolahan ikan dengan 10-14 wanita nelayan sasaran, yang terbentuk dalam kelompok kerja (kelompok usaha pengolahan hasil perikanan). Kegiatan yang dilakukan meliputi: persiapan, sosialisasi dan penyuluhan, konsolidasi kelembagaan dan evaluasi kegiatan.

\section{Hasil dan Pembahasan}

Pelaksanaan kegiatan program pengabdian kepada masyarakat yang berjudul, "Pemberdayaan Ekonomi Masyarakat Pesisir Melaui Peningkatan Ketrampilan Pengolahan Hasil Perikanan di Desa Labuan Lombok, Kecamatan Pringgabaya Kabupaten Lombok Timur ", dilaksanakan pada minggu pertama bulan November 20120 yang diawali dengan Sosialisasi kegiatan program dan penyuluhan lanjutan dilakukan pada tanggal 7 November 2020, yang di mulai pukul 9.00 - 12.00 WITA, dengan sasaran wanita nelayan anggota kelompok pengolahan hasil perikanan (pemindang ikan) dengan tetap melakukan koordinasi dengan pihak yang terkait dan tetap memperhatikan aturan penangan Covid 19. Hasil sosialisasi tersebut disepakati bahwa Lokasi penyuluhan adalah salah satu rumah anggota kelompok pengolahan ikan di Desa Labuhan Lombok Kecamatan Pringgabaya Lombok Timur. Materi yang dberikan meliputi: 
Teknologi Pengolahan Hasil Perikanan (Pemindangan Ikan) Dalam Upaya Meningkatkan Kesejahteraan Nelayan, dan Unsur-unsur Pokok Dalam Proses Penumbuhan Kehidupan Berkelompok (Kelompok Wanita Nelayan). Selain itu juga diberikan pengetahuan tentang prinsip, prosedur, bahanbahan, peralatan dan faktor yang berpengaruh terhadap pengolahan hasil perikananm pentingnya penerapan sanitasi dan higienis dalam proses produksi.

Kegiatan pengabdian kepada masyarakat ini dilakukan dengan memberikan pengetahuan kepada wanita nelayan tentang upgrading/perbaikan teknolog pemindangan ikan. Khalayak sasaran yang mendukung kegiatan tersebut adalah kelompok wanita nelayan pemindang ikan.

Masyarakat di Desa Labuahan Lombok, khusunya wanita pengolah hasil perikanan ikan menyambut baik kegiataan Tim Pengabdian kepada Masyarakat Fakultas Pertanian, Universitas Mataram. Wanita nelayan pemindang ikan tertarik dan berminat untuk ikut serta dalam pelaksanaan kegiatan pengabdian ini. Jumlah peserta sebanyak 16 orang wanita nelayan, yang semuannya anggota kelompok pengolahan hasil perikanan (pemindang ikan). (Gambar 1).

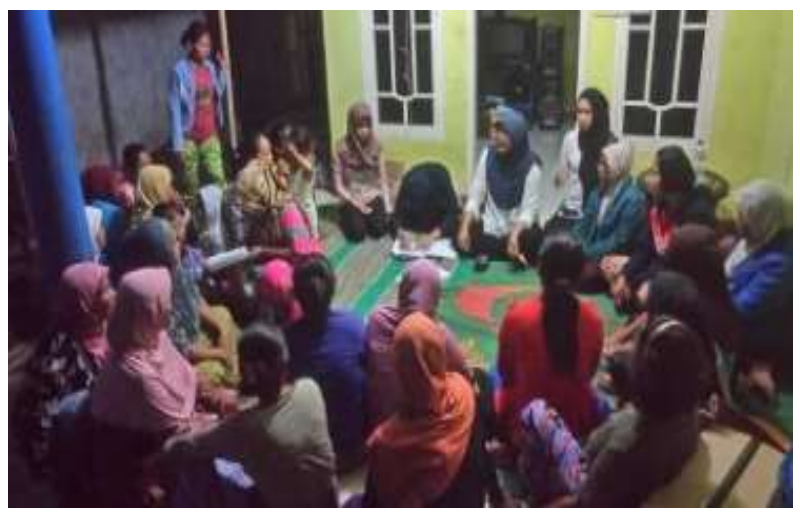

Gambar 1. Kegiatan Pelatihan Pemberdayaan Ekonomi Kelompok Wanita Nelayan

Diskusi dilakukan dalam dua arah sehingga peserta dapat lebih faham mengenai materi yang disampaikan. Dalam diskusi/tanya jawab tersebut, tim pengabdian menampung/mencatat semua pertanyaan yang diajukan oleh anggota kelompok wanita pengolah hasil perikanan, tentang materi yang disampaikan. Selanjutnya Tim pengabdian pada masyarakat memberikan jawaban atas segala pertanyaan tersebut, sehingga anggota kelompok wanita nelayan mengerti dan merasa puas. Jawaban yang diberikan oleh Tim Penyuluh diharapkan dapat dijadikan pedoman oleh Kelompok nelayan khususnya wanita pemindang ikan dalam mengembangkan fungsinya.Pada akhir acara tim mengajukan beberapa pertanyaan kepada peserta dengan maksud untuk mengetahui sejauh mana materi-materi yang telah disampaikan dapat dimengerti dan dipahami oleh peserta penyuluhan.

Berdasarkan hasil pengamatan dan evaluasi yang dilakukan baik pada saat penyampaian materi maupun setelah penyampaian materi, ditemukan fenomenafenomena yang menunjukkan keberhasilan kegiatan pengabdian ini baik bagi Tim maupun bagi peserta sebagai kelompok sasaran. Beberapa hasil yang diperoleh peserta penyuluhan dan Tim dengan dilaksanakannya pengabdian pada masyarakat ini di antaranya adalah: (1) Meningkatkan pengetahuan dan ketrampilan wanita nelayan anggota kelompok pengolahan hasil perikanan tentang aspek teknik, aspek sosial ekonomi dan lainnya ; (2) Meningkatkan kesadaran sosial wanita nelayan akan pentingnya kebersamaan dalam suatu ikatan kelompok; (3) Menunjukkan kepada masyakat, khusunya kaum wanita nelayan tentang teknik pengolahan ikan yang baik, sehat, dan ramah lingkungan; (4) Menjalin hubungan antara perguruan tinggi, khususnya Universitas Mataram dengan masyarakat; dan (5) Bertambahnya pengetahuan dan kemampuan manajemen usaha masyarakat pesisir, khusunya wanita nelayan anggota kelompok pengolah hasil perikanan (pemindang ikan) dalam upaya memanfaatkan potensi yang ada serta mencipkan hubungan 
kerjasama yang saling menguntungkan antara kelompok wanita pengolah pengolah hasil perikanan dengan pemerintah. Selain itu juga bertambahnya wawasan wanita nelayan anggota kelompok terutama yang menyangkut langkah-langkah yang perlu ditempuh dalam upaya meningkatkan kualitas dan kuantitas usaha pengolahan hasil perikanan (pemindangan ikan) dan upaya-upaya untuk meningkatkan pendapatan, serta terciptanya komunikasi timbal balik antara Lembaga Perguruan Tinggi, dalam hal ini Tim Penyuluh Fakultas Pertanian UNRAM dengan wanita nelayan, khususnya pemindang ikan, sehingga kedua belah pihak terjadi "take and give" (saling memberi dan menerima) yang selanjutnya dapat menunjang pengembangan aktivitas masing-masing.

Secara keseluruhan kegiatan pengabdian pada masyarakat ini cukup berhasil. Hal ini tercermin dari kesungguhan/keseriusan para peserta dalam mengikuti dan menanggapi setiap materi yang disampaikan. Keadaan seperti ini sekaligus merupakan indikator adanya relevansi yang kuat antara pokok materi yang disampaikan dengan kebutuhan/masalah yang dihadapi wanita nelayan khususnya pemindang ikan.

$$
\text { Fenomena yang ditunjukkan }
$$

oleh peserta seperti diuraian di atas, hanya dapat digunakan sebagai petunjuk adanya kemampuan peserta dalam "aspek kognitif dan "aspek afektif". Akan tetapi belum dapat dijadikan tolok ukur untuk mengetahui apakah telah terjadi perubahan perilakuk (aspek psikomotorik) dalam diri petani peserta. Oleh sebab itu, untuk mengetahui apakah materi yang telah disampaikan benar-benar diterapkan oleh peserta (wanita nelayan khusunya pemindang ikan), maka diperlukan pengamatan dan pemantauan lebih lanjut di lapangan.

Untuk keperluan pemantauan lebih la njut ini, Tim Pengabdian pada masyarakat telah menyatakan kesediaan untuk terus menjalin komunikasi, baik dengan aparat terkait, sehinggadari waktu ke waktu terjadi perubahan yang semakin menguntungkan kelompok wanita nelayan dan anggotanya

Dalam

penyuluhan

rangkaian anggotanya kegiatan perencanaan sampai pada implementasi (pelaksanaannya) di lapangan, secara umum dapat dikatakan berjalan dengan lancar dan sukses, tetapi disadari juga masih dijumpai beberapa hambatan. Hambatan yang dijumpai masih berkisar pada masalah komunikasi dalam menyampaikan materi penyuluhan. Hal ini disatu sisi disebabkan oleh kurangnya kemampuan tim penyuluh menggunakan bahasa daerah (Bugis, dan Sasak) dalam penyampaian materi, dan disisi laian adanya sebagian peserta penyuluh yang kurang mampu memahami bahasa Indonesia dengan baik. Selain itu, adanya perbedaan latar belakang pendidikan dan pengetahuan, umur, serta kondisi sosial ekonomi di antara peserta penyuluh. Hambatan-hambatan tersebut dikhawatirkan akan dapat menghambat pemahaman dan kurang meratanya daya serap diantara peserta terhadap materi yang disuluhkan.

Keberhasilan kegiatan penyuluhan yang dilaksanakan ini tidak lepas dari adanya faktor pendorong di antaranya : (1) Ketepatan menentukan lokasi penyuluhan dengan pokok masalah yang disuluhkan. Pokok masalah yang disuluhkan tersebut benarbenar merupakan masalah dan kebutuhan masyarakat, khusunya wanita nelayan, anggota kelompok pengolahan hasil perikanan (pemindangan ikan) di lapangan; (2) Adanya rasa antusias/perhatian yang tinggi dari peserta penyuluhan untuk lebih maju, baik dalam cara berusahatani maupun dalam meningkatkan taraf hidupnya. Hal ini tercermin dari kesungguhan dalam mengikuti penyuluhan, yaitubersemangat dalam memper hatikan setiap materi, kritis dalam menanggapi setiap materi penyuluhan dan berani dalam mengajukan setiap masalah yang dihadapi; (3) Bantuan dan kerjasama 
yang baik antara Tim Penyuluh Fakultas Pertanian UNRAM dengan masyarat anggota kelompaok nelayan pengolah hasil perikanan (pemindangan ikan) di Desa Labuhan Lombok Kecamatan Pringgabaya Kabupaten Lombok Timur. Hal ini terlihat dari lancarnya pelaksanaan pengabdian pada masyarakat berupa penyuluhan mulai dari persiapan, perijinan, konfirmasi waktu, tempat dan peserta penyuluhan, sampai pada pelaksanaan penyuluhan di lapangan.

\section{Kesimpulan}

Kegiatan pelaksanaan kegiatan pengabdian kepada masyarakat ini dapat disimpulkan sebagai berikut: (1) Kegiatan pengabdian pada masyarakat ini telah mampu meningkatkan pengetahuan dan ketrampilan peserta terutama yang berkaitan dengan: (a) aspek teknik, aspek sosial ekonomi dan lainnya dari usaha pengolahan hasil perikanan (pemindangan ikan) ; (b) teknik pengolahan hasil perikanan yang baik, sehat, dan ramah lingkungan; dan (c) kemampuan manajemen kelompok masyarakat pesisir, khusunya wanita nelayan pengolah hasil perikanan dalam upaya memanfaatkan potensi yang ada; (2) Kegiatan pengabdian pada masyarakat ini juga telah ikut mendorong semakin intensifnya komunikasi timbal balik antara perguruan tinggi dalam hal ini Fakultas Pertanian, UNRAM dengan masyarakat pesisir, khusunya khusnya wanita yang tergabung dalam kelompok nelayah pengolah hasil perikanan (pemindang ikan) yang ada di Desa Labuhan Lombok, Kecamatan Pringgabaya, Kabupaten Lombok Timur.

\section{Saran}

Dari hasil kesimpulan di atas maka dapat disarankan bahwa:

(1) Masyarakat pesisir, khusunya wanita nelayan pengolah hasil perikanan (pemindang ikan) dapat memanfaatkan pengetahuan yang diperoleh dalam upaya peningkatan teknik pengolahan, kualitas, dan kuantitas prodak perikanan serta dapat meningkatkan kesejahteraanya; (2) Diharapkan kepada penyuluh perikanan di Desa Labuhan Lombok, Kecamatan Pringgabaya Lombok Timur dan petuga TPI Labuhan Lombok serta aparat desa dapat memberikan bimbingan secara langsung kepada wanita nelayan yang tergabung dalam kelompok pengolah hasil perikanan dengan cara melakukan demontrasi-demontasi; dan (3) Pengabdian pada masyarakat seperti ini perlu ditingkatkan frekuensinya dengan menggunakan pendekatan penyuluhan yang lebih efektif.

\section{Daftar Pustaka}

BPS Kabupaten Lombok Timur. 2020a. Kecamatan Pringgabaya Dalam Angka 2020. Selong: BPS Kabupaten Lombok Timur.

BPS Kabupaten Lombok Timur. 2020. Kabupaten Lombok Timur Dalam Angka 2020. Selong: BPS Kabupaten Lombok Timur.

Kusnadi, 2006. Akar Kemiskinan Nelayan. Yogyakarta: LKiS Pelangi Aksara.

Naui, A.S. dan Nikmawatisusanti, Y. 2016. Peningkatan Keterampilan dan Pendapatan Masyarakat Nelayan Melalui Kegiatan Pengolahan Hasil Perikanan di Desa Bumbulan Kecamatan Paguat Kabupaten Puhuwato. Laporan Akhir KKS Pengabdian Masyarakat. Universitas Negeri Gorontalo.

Subagiana, IGM, Wijayati, N.L.M., Artatanaya, I.GL.S. 2018. Model Pemberdayaan Ekonomi Masyarakat Pesisir (PEMP) pada Tiga Perkampungan Nelayan Air Kuning, Pengambengan dan Candi Kusuma Kabupaten Jembrana Propinsi Bali (Suatu Studi Komparatif) Jurnal Bisnis dan Kewirausahaan, Vol. 14, No. 2, Juli 2018. Denpasar

Yusuf, M., Husni, S., Abubakar , 2018. Analisis Tingkat Kesejahteraan Nelayan Kecil Berdasarkan Indikator Nilai Tukar Nelayan (NTN) Studi Kasus di Desa Teanjung Luar Kabupaten Lombok Timur (Jurnal AGRIMANSION Vo.19 No. 3 Desember 2018; ISSN 1411 -8261) 